\title{
Diversity and Phenology of the Braconid Community (Hymenoptera: Braconidae) in the Mediterranean Protected Landscape of Sierra Calderona (Spain)
}

\author{
Jose Vicente Falcó-Garí, Francisco Javier Peris-Felipo*, Ricardo Jiménez-Peydró \\ Laboratory of Entomology and Pest Control, Institute Cavanilles of Biodiversity and Evolutionary Biology, \\ Valencia, Spain \\ Email: ${ }^{*}$ Francisco.peris@uv.es
}

Received 8 November 2013; revised 8 December 2013; accepted 16 December 2013

Copyright (C) 2014 by authors and Scientific Research Publishing Inc.

This work is licensed under the Creative Commons Attribution International License (CC BY).

http://creativecommons.org/licenses/by/4.0/

(c) (i) Open Access

\begin{abstract}
The diversity of the Braconidae subfamilies (Hymenoptera) in the protected landscape of the Natural Park of Sierra Calderona (Eastern Spain) is analysed. Samplings have been carried out along 2010 in three different habitats: almond crop, Oak forest (Quercus suber $\mathrm{L}$.) and Pine forest (Pinus halepensis Miller). In total, 2166 braconid specimens, belonging to 23 subfamilies, have been captured. Alpha, beta and gamma diversities are analysed. As a result, almond crop habitat is proven to show the greatest diversity. The structure of the community and the phenology in each habitat are also analysed.
\end{abstract}

Keywords

Braconidae; Diversity; Community; Mediterranean Landscapes; Spain

\section{Introduction}

Mediterranean forests are very rich in evergreen species, frequently intersected by areas of brushwood, pasture, farming and ranching. In close proximity to these areas, however, it is often possible to identify zones that have regained their highly diverse natural communities after the cessation of human intervention. This fact favours the proliferation of "hot spots" in Mediterranean ecosystems [1]. Despite the huge resistance posed by Mediter-

${ }^{*}$ Corresponding author.

How to cite this paper: Falcó-Garí, J.V., et al. (2014) Diversity and Phenology of the Braconid Community (Hymenoptera: Braconidae) in the Mediterranean Protected Landscape of Sierra Calderona (Spain). Open Journal of Ecology, 4, $174-181$. http://dx.doi.org/10.4236/oje.2014.44018 
ranean biotopes to human pressure, isolation and fragmentation are unavoidable [2], resulting in the emergence of isolated patches within the landscapes.

The data provided from the studies on arthropods can be very valuable for the adoption of measures aimed to guaranteeing the diversity and welfare of protected forests [3]-[5], especially insect populations with a high sensitivity to alterations in environmental resources and conditions. Parasitic Hymenoptera of the Braconidae family are especially pertinent in this respect due to their particular biology [6].

Braconidae is the second largest family within Hymenoptera with approximately 40,000 species catalogued around the World. The majority of species are primary parasitoids of immature stages of Lepidoptera, Coleoptera and Diptera [7]. These wasps are of enormous ecological interest because of their role in controlling the natural phytophagous insect populations, causing direct effects in the host species' population size and indirect effects on the diversity and survival of host plants [8]. Additionally, they can indicate the presence or absence of related host and plant populations [8] [9]. Finally, some species can also be relevant from an economic point of view, because of their potential for pest control [10].

Because of the type of relationship established between Braconidae populations and host species, which are subsequently affected by the climatic factors and human activities, Braconidae (especially those adopting koinobiont strategies) can be considered a valid parameter for the determination of human effects on these communities and the assessment of specific diversity within a region [11].

Although many studies have been done on diversity of Braconidae, worldwide, for example in Brazil [12] [13], Venezuela [14] [15] or in the Iberian Peninsula (Andorra, Spain and Portugal) [16], these communities have been insufficiently analysed. Recent studies have specially emphasized on diversity of Braconids in the North of Spain [17]-[19].

In this context, diversity and community structure of the family Braconidae in three different habitats of the Natural Park of Sierra Calderona (Eastern Spain) are analysed and information about its phenology is provided.

\section{Material and Methods}

\subsection{Area of Study}

Samples were taken in the Natural Park of Sierra Calderona. This area covers 18.019 ha, located between Valencia and Castellon provinces (UTM 30SYK71). It consists of a mountain range, orientated in a NW-SE direction, which separates the basins of the rivers Túria and Palancia. This Natural Park is one of the most valuable landscapes of Valencian Community because its physical-natural characteristics afford it a great ecological and landscape interest. The rugged terrain and significant slopes, along with the presence of both carbonate and siliceous materials, promote the development of diverse vegetation. However, human activity and forest fires have relegated the climax vegetation to the ravines and inaccessible areas. The vegetation of this area is typically Mediterranean, and the predominant species are Pinus halepensis Mill and Quercus suber L., interspersed with areas of crops and herbaceous plants [20]. This Natural Park is characterized by the Mediterranean climate of moderate temperatures, with an average of $17^{\circ} \mathrm{C}$, and strong irregular rainfall with average values ranging from $350 \mathrm{~mm}$ to $600 \mathrm{~mm}$. The normal pattern is drought in summer, torrential rainfall in autumn and occasional snow on the coldest days of winter (information of climatic conditions provides from AEMET (state agency of Meterology)) [20].

\subsection{Samplings Design and Data Collection}

Specimen capture was carried out by Malaise traps (Townes model) distributed in three different habitats: Oak forest (mainly populated by Quercus suber L.), Pine forest (populated by Pinus halepensis Miller) and almond crop (populated by Prunus amygdalus L. and some Prunus avium L., and surrounded by Quercus and Pinus).

Sampling took place weekly along the year 2010, with a few exceptions due to unforeseeable circumstances. The captured of specimens were preserved in ethanol 70\% until final preparation.

Braconid specimens were identified to subfamily level in accordance with Achterberg [21]. The studied specimens are deposited in the Entomological Collection of the University of Valencia (Valencia, Spain; ENV).

\subsection{Data Analysis}

Data obtained by samples were used in richness analyses, diversity indices and correspondence analyses to identify possible relationships between taxa distributions within each habitat; similarity/dissimilarity analyses to 
identify the relationship between taxa; phenological analyses and community analyses. All analyses were carried out using PAST (Paleontological Statistics Software Package for Education and data analysis) [22].

In order to complete the diversity analyses and to investigate the community structure, log-series, log-normal and broken-stick models were also applied [23]. The log-series model represents an unstable community, composed of a few abundant species and a high number of rare species. The broken-stick model refers to maximum occupation of an environment, with equitable sharing of resources between species. Finally, the log-normal model reflects an intermediate situation between the other two models [24]. Using the data obtained from this park, each of these models was applied to calculate the expected number of taxa- $\log _{2}$, grouping taxa according to abundance [23] [25] [26]. To test the significance of the models, expected taxa values were compared with those from observed taxa using chi-square analysis [27].

\section{Results and Discussion}

During the sampling period, 2166 specimens of Braconidae were collected, distributed in 23 subfamilies: Adeliinae (8), Agathidinae (5), Alysiinae (207), Aphidiinae (505), Blacinae (11), Brachistinae (34), Braconinae (238), Cheloninae (247), Doryctinae (89), Euphorinae (35), Exothecinae (4), Gnamptodontinae (7), Helconinae (2), Homolobinae (3), Hormiinae (7), Ichneutinae (6), Lysiterminae (4), Macrocentrinae (1), Microgastrinae (614), Miracinae (31), Opiinae (64), Orgilinae (14) and Rogadinae (30) (Table 1).

However, the subfamilies were not evenly distributed when different habitats are considered separately. Thus, 21 subfamilies were identified in almond crop, 16 were identified in Oak forest and 11 were identified in Pine forest.

On the other hand, when the number of captures is analysed, it was observed that 1748 specimens were collected in almond crop, 373 in Oak forest and 45 in Pine forest. In almond crop habitat, the most captured subfamily was Microgastrinae (549 specimens) followed by Aphiidinae (428). However, in Oak forest the most abundant subfamilies was Cheloninae and Alysiinae (80, 79 respectively) and in Pine forest the most captured subfamily was Rogadiinae (10), followed by Alysiinae and Euphorinae (8 specimens each one).

These results could be explained in terms of composition of flora and fauna in each one of the habitats. Firstly, in almond crop, it should be noted the high presence of Microgastrinae and Aphiidinae which are specifically parasitoids of Lepidoptera and Aphididae, respectively. These insect groups cause damage in crops and they could be present in high numbers. On the other hand, in Oak forest, it is possible to notice the greater presence of Cheloninae and Alysiinae, parasitoids of Lepidoptera and Diptera. Finally, in Pine forest predominates the presence of Euphorinae (parasitoids of Coleoptera and Hemiptera), followed by Alysiinae and Rogadinae (parasitoids of Diptera and Lepidoptera, respectively). The greater abundance of Rogadinae could be attributed to the maturity of the forest with pines with 30 - 40 years old.

When analyzing the structure of the community, it was needed to distinguish between two types of analyses: proportional abundance indices and the parametric models. First, the community structure is studied by proportional abundance indices in which differentiate dominance indices (Simpson index) and equity indices (Shannon-Wiener index) were used.

The analysis obtained with the Simpson index (Table 2) showed a dominance of the community structure by one or more subfamilies with high population abundance. This was also reflected by Shannon index (Table 2), so it is suggested a similar trend in the distribution of dominant subfamily or subfamilies. With these results it is possible to notice that in Pine forest there is higher subfamily diversity, followed by almond crop and Oak forest habitat.

Finally, applying parametric models, (Table 3) the analysis of the community structure showed that Sierra Calderona presents compliance with log-series and log-normal models presenting, more or less, the same p-value ( 0.63 and 0.24 respectively). This fact could indicate two types of community structure. On the one hand, this community could be unstable and composed by few abundant species and large number of rare species. On the other hand, it could indicate the very specific botanical and faunal composition as well as climatic conditions that the samplings area had. Thus, the subfamilies' number of this community was conditioned by a large number of factors associated with high temperatures and low rainfall that occurred in this area causing that species must adapt to conditions very strictly.

In order to obtain beta diversity values (similarity/dissimilarity) between the different areas under consideration, the Jaccard index was calculated (Table 4). The resulting values indicated a certain degree of dissimilarity 
Table 1. Subfamily distribution and specimen number according to habitat.

\begin{tabular}{|c|c|c|c|c|}
\hline & Almond crop & Oak forest & Pine forest & Total \\
\hline Adeliinae & 8 & 0 & 0 & 8 \\
\hline Agathidinae & 4 & 0 & 1 & 5 \\
\hline Alysiinae & 110 & 89 & 8 & 207 \\
\hline Aphidiinae & 428 & 74 & 3 & 505 \\
\hline Blacinae & 8 & 3 & 0 & 11 \\
\hline Brachistinae & 29 & 4 & 1 & 34 \\
\hline Braconinae & 227 & 9 & 2 & 238 \\
\hline Cheloninae & 153 & 90 & 4 & 247 \\
\hline Doryctinae & 79 & 10 & 0 & 89 \\
\hline Euphorinae & 17 & 10 & 8 & 35 \\
\hline Exothecinae & 4 & 0 & 0 & 4 \\
\hline Gnamptodontinae & 1 & 6 & 0 & 7 \\
\hline Helconinae & 1 & 1 & 0 & 2 \\
\hline Homolobinae & 3 & 0 & 0 & 3 \\
\hline Hormiinae & 5 & 2 & 0 & 7 \\
\hline Ichneutinae & 0 & 5 & 1 & 6 \\
\hline Lysiterminae & 0 & 4 & 0 & 4 \\
\hline Macrocentrinae & 1 & 0 & 0 & 1 \\
\hline Microgastrinae & 549 & 60 & 5 & 614 \\
\hline Miracinae & 31 & 0 & 0 & 31 \\
\hline Opiinae & 61 & 3 & 0 & 64 \\
\hline Orgilinae & 12 & 0 & 2 & 14 \\
\hline Rogadinae & 17 & 3 & 10 & 30 \\
\hline TOTAL & 1748 & 373 & 45 & 2166 \\
\hline
\end{tabular}

Table 2. Diversity and abundance values for collected Braconidae.

\begin{tabular}{cccc}
\hline & Almond crop & Oak forest & Pine forest \\
\hline Number of subfamilies & 21 & 16 & 11 \\
Number of specimens & 1748 & 373 & 45 \\
Shannon-Wiener & 1.99 & 1.96 & 2.11 \\
Simpson & 0.80 & 0.81 & 0.85 \\
\hline
\end{tabular}

Table 3. Expected frequency of species (exp f) according to abundance models (log-series, log-normal and broken-stick) for the Braconidae in Serra Calderona Natural Park.

\begin{tabular}{|c|c|c|c|c|c|c|}
\hline \multirow[b]{2}{*}{ Class } & \multicolumn{2}{|c|}{ Log-series } & \multicolumn{2}{|c|}{ Log-normal } & \multicolumn{2}{|c|}{ Broken-stick } \\
\hline & $\operatorname{Exp} \mathrm{f}$ & Obs $\mathrm{f}$ & $\operatorname{Exp} f$ & Obs $\mathrm{f}$ & $\operatorname{Exp} f$ & Obs $f$ \\
\hline 0 & - & - & 2.34 & - & - & - \\
\hline 1 & 5.39 & 2 & 3.58 & 2 & 0.46 & 2 \\
\hline 2 & 2.08 & 3 & 1.29 & 3 & 0.45 & 3 \\
\hline 3 & 2.26 & 5 & 1.99 & 5 & 0.87 & 5 \\
\hline 4 & 2.33 & 2 & 2.18 & 2 & 1.65 & 2 \\
\hline 5 & 2.34 & 3 & 1.99 & 3 & 2.94 & 3 \\
\hline 6 & 2.28 & 3 & 1.88 & 3 & 4.66 & 3 \\
\hline 7 & 2.12 & 1 & 1.48 & 1 & 5.83 & 1 \\
\hline 8 & 1.83 & 3 & 1.30 & 3 & 4.55 & 3 \\
\hline 9 & 1.35 & 1 & 0.68 & 1 & 1.37 & 1 \\
\hline 10 & 0.75 & 1 & 0.52 & 1 & 0.06 & 1 \\
\hline \multirow[t]{3}{*}{11} & 0.23 & 0 & 0.30 & 0 & 0.00 & 0 \\
\hline & \multicolumn{2}{|c|}{$X^{2}=7.928$} & \multicolumn{2}{|c|}{$X^{2}=13.811$} & \multicolumn{2}{|c|}{$X^{2}=59.53$} \\
\hline & \multicolumn{2}{|c|}{$p=0.635$} & \multicolumn{2}{|c|}{$\mathrm{p}=0.243$} & \multicolumn{2}{|c|}{$\mathrm{p}=0.000$} \\
\hline
\end{tabular}


between habitats although, almond crop and Oak forest are the closest habitats $\left(\mathrm{I}_{\mathrm{J}}=0.60\right)$, while almond crop and Pine forest are the farthest habitats $\left(\mathrm{I}_{\mathrm{J}}=0.45\right)$. These results were also observed in the Jaccard cluster obtained through cluster analysis, of which the level of correlation was $r=0.95$ (Figure 1).

However, the Principal Component Analysis (PCA) (Figure 2) shows that there are many own subfamilies for almond crop (4) and one subfamily for Oak forest, while Pine forest has not any own subfamily. The rest of subfamilies are usually presently shared (14 for crop-Oak forest, 10 for crop-Pine forest and 9 for Oak forest-Pine forest).

The indices of species replacement by the Whittaker index (Table 4) showed that almond crop and Oak forest has the high replacement between different habitats of Sierra Calderona with $43.75 \%$, followed by almond crop and Pine forest with $37.50 \%$, while between Oak forest and Pine forest there are not a lot of replacements with only $12.50 \%$ of the subfamilies.

The Complementarity index (C) (Table 4) suggested that almond crop and Pine forest has the highest complementarity (54.50\%) followed by Oak forest and Pine forest with $50.00 \%$ and almond crop and Oak forest with $39.10 \%$. These results showed a fair degree of complementarity, but also indicated the presence of different subfamilies in each habitat.

Finally, gamma diversity reached a value of 22.99 , which is practically identical to the value of the total subfamily richness caught in the three habitats of Natural Park of Sierra Calderona (subfamily number $=23$ ).

On the other hand, with the analyses of the phenology during the collection period, it is possible to check the presence periods of Braconidae, all data from each habitat were pooled. With these data (Figure 3), it is possible to notice that specimens belonging to this family can be found throughout the year, although their abundance is

Table 4. Values of diversity indices for Braconidae subfamily within and between the habitats.

\begin{tabular}{ccccccc}
\hline & \multicolumn{2}{c}{ Jaccard index } & \multicolumn{2}{c}{ Whittaker index (\%) } & \multicolumn{2}{c}{ Complementarity (C) indices (\%) } \\
\cline { 2 - 6 } & Oak forest & Pine forest & Oak forest & Pine forest & Oak forest & Pine forest \\
\hline \multirow{2}{*}{ Almond } & 0.60 & 0.45 & 43.75 & 37.50 & 39.13 & 54.54 \\
Oak & & 0.50 & & 12.50 & & 50.00 \\
\hline
\end{tabular}

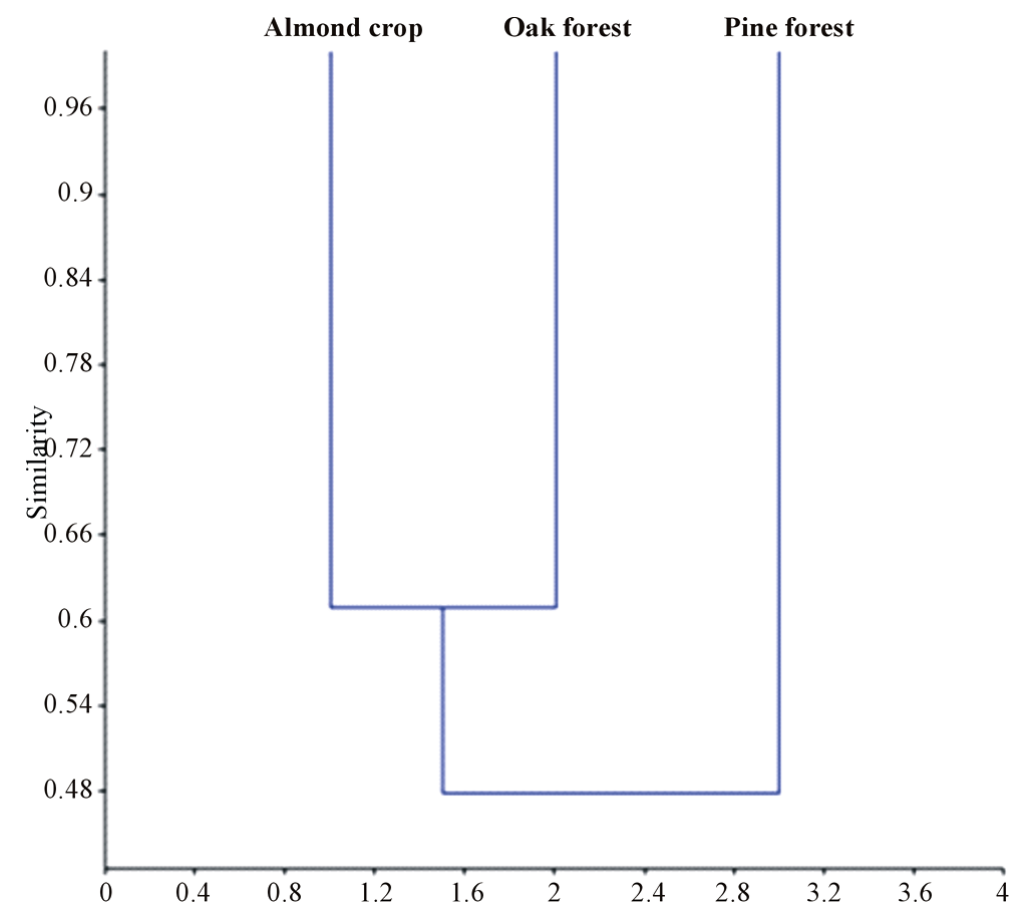

Figure 1. Cluster of Jaccard analysis reflecting relationship between habitats in Natural Park of Sierra Calderona. 


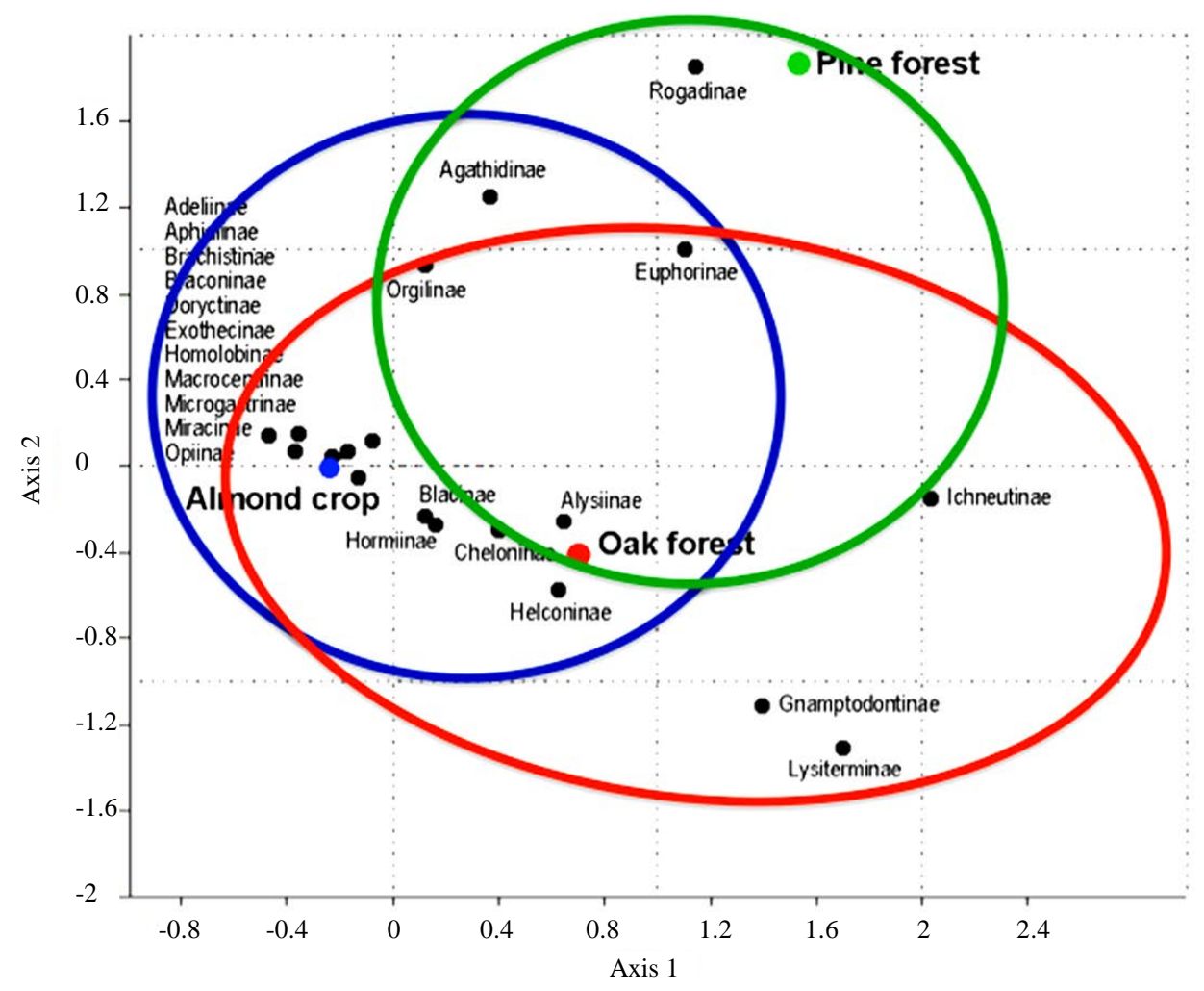

Figure 2. Principal Component Analysis (PCA).

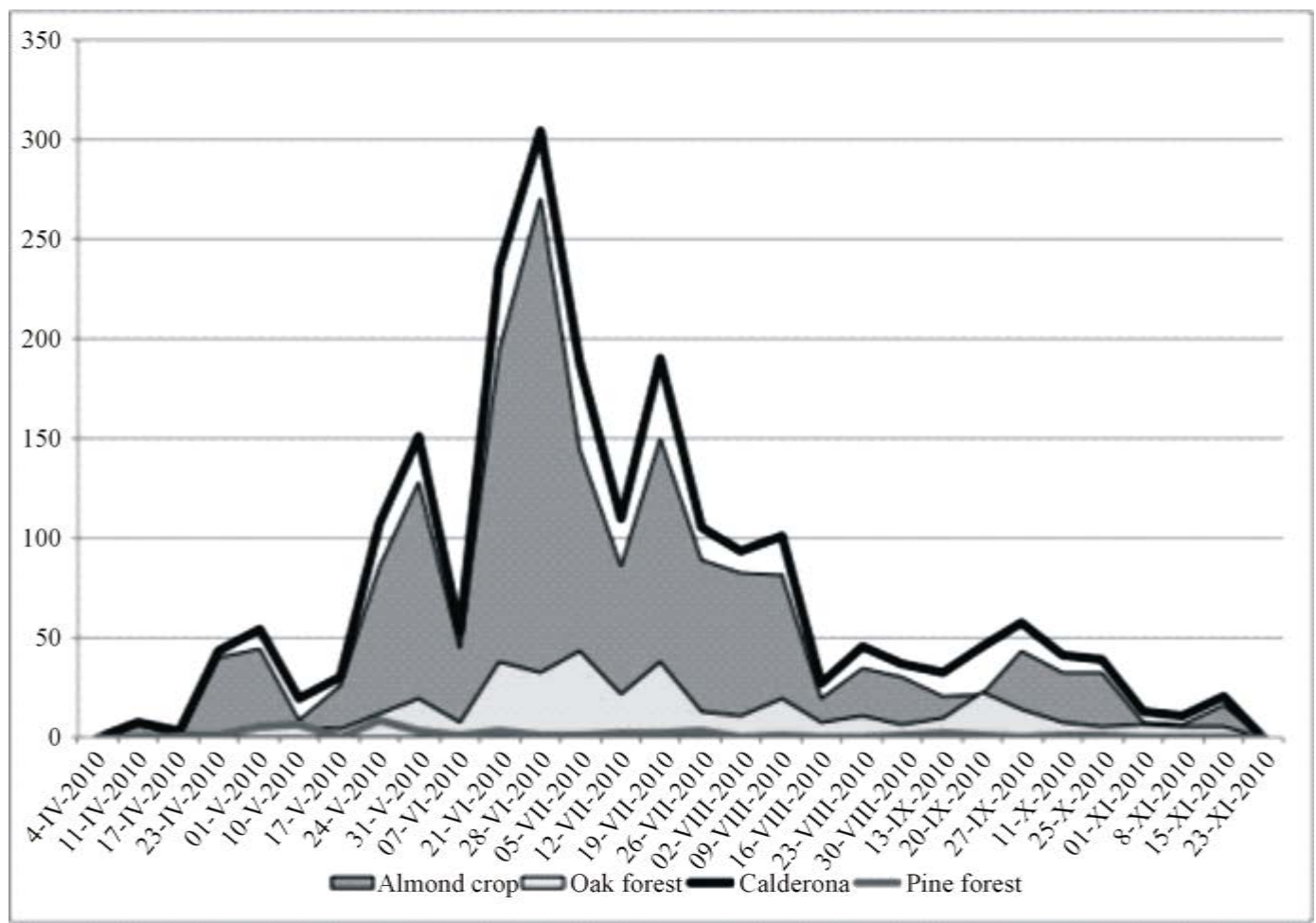

Figure 3. Phenology of Braconidae in Natural Park of Sierra Calderona.

higher from May to July (spring) and its minor in the rest of months. There were two peaks, fluctuated in num- 
ber of captured specimens. The first corresponds to spring (March-July) and the second to autumn (SeptemberOctober). On the other hand, the phenology changes with the habitat also. Then, in Pine forest and almond crop spring is the period with high presence of braconids, while in Oak forest there are two differentiated peaks, one in spring (June-July) and another one in autumn (September-October).

This kind of studies conducted to determine the biodiversity is very important because they increase the knowledge about the faunal composition in our landscapes. However, it will be also recommended further studies of Braconidae in different areas as DNA-barcoding or MAPL (Molecular analysis of parasitoid linkages) [28] studies to increase the knowledge of this large group that is still largely ecologically unknown due to these studies allow to know the application of these species in the biological control.

\section{Acknowledgements}

We wish to thank to Javier Calatayud, the farm Falaguera owner, for his great help and his kindness during fieldwork and, also, to the staff of Natural Park of Sierra Calderona.

\section{References}

[1] Myers, N., Mittermeier, R.A., Mittermeier G.G., Da Foseca, G. and Kent, J. (2000) Biodiversity Hotspots for Conservation Priorities. Nature, 403, 853-858. http://dx.doi.org/10.1038/35002501

[2] Pungetti, G. (2003) Diseño Ecológico del Paisaje. Planificación y Conectividad en el Mediterráneo y en Italia. In: Mora, M.R.G., Ed., Las Áreas Protegidas en la Cuenca Mediterránea. Junta de Andalucía, RENPA y IUCN, Sevilla, 111124.

[3] Pyle, R., Bentzien, M. and Opler, P. (1981) Insect Conservation. Annual Review of Entomology, 26, $233-258$. http://dx.doi.org/10.1146/annurev.en.26.010181.001313

[4] Pearson, D.L. and Cassola, F. (1992) World-Wide Species Richness Patterns of Tiger-Beetles (Coleoptera: Cicindelidae): Indicator Taxon for Biodiversity and Conservation Studies. Conservation Biology, 6, 376-391. http://dx.doi.org/10.1046/j.1523-1739.1992.06030376.x

[5] Kremen, C., Colwell, R.K., Erwin, T.L., Murphy, D.D., Noss, R.F. and Saujayan, M.A. (1993) Terrestrial Arthropod Assemblages: Their Use as Indicators in Conservation Planning. Conservation Biology, 7, 796-808. http://dx.doi.org/10.1046/j.1523-1739.1993.740796.x

[6] Wharton, R.A., Marsh, P.M. and Sharkey, M.J. (1997) Manual of the New World Genera of the Family Braconidae (Hymenoptera). The International Society of Hymenopterists, Washington, n.1.

[7] Sharkey, M.J. (1993) Family Braconidae. In: Goulet, H. and J. T. Huber, Eds., Hymenoptera of the World: An Identification Guide to Families. Agriculture Canada, Ottawa, 362-395.

[8] La Salle, J. and Gauld, I.D. (1992) Parasitic Hymenoptera and the Biodiversity Crisis. Redia, 74, 315-334.

[9] Matthews, E.G. (1974) A Revision of the Scarabaeine Dung Beetles of Australia: II. Tribe Scarabaeini. Australian Journal of Zoology Supplementary Series, 24, 1-211. http://dx.doi.org/10.1071/AJZS038

[10] González, H.D. and Ruíz, D.B. (2000) Los Braconidos (Hymenoptera: Braconidae) Como Grupo Parámetro de Biodiversidad en las Selvas Deciduas del trópico: Una Discusión Acerca de su Posible uso. Acta Zoológica Mexicana, 79, 43-56.

[11] Delfín, G.H. and Burgos, R.D. (2000) Los bracÓnidos (Hymenoptera: Braconidae) Como Grupo Parámetro de Biodiversidad en las selvas Deciduas del Trópico: Una Discusión Acerca de su Posible Uso. Acta Zoológica Mexicana, 79, 43-56.

[12] Cirelli, K.R.N. and Penteado-Dias, A.M. (2003) Fenologia dos Braconidae (Hymenoptera: Ichneumonoidea) da Área de Proteçao Ambiental (APA) de Descalvado, SP. Revista Brasileira de Entomolgia, 47, 99-105. http://dx.doi.org/10.1590/S0085-56262003000100015

[13] Scatolini, D. and Penteado-Dias, A.M. (2003) Análise Faunística de Braconidae (Hymenoptera) em Três Áreas de Mata Nativa do Paraná, Brasil. Revista Brasileira de Entomologia, 47, 187-195. http://dx.doi.org/10.1590/S0085-56262003000200006

[14] Briceño, R., Torres, D. and Romero, L. (2007) Composición Faunística y Distribución de la Familia Braconidae (Hymenoptera: Ichneumonoidea) en tres Ecosistemas Naturales de Venezuela. Folia Entomológica Mexicana, 6, 14131418.

[15] Briceño, R., Torres, D. and Zaldívar-Riveron, A. (2009) Primer Reporte de la Familia Braconidae (Hymenoptera: Ichneumonoidea) en los Parques Cerro Sarroche y Terepaima, Estado Lara, Venezuela. Bioagro, 21, 223-226. 
[16] Falcó-Garí, J.V., Oltra-Moscardó, M.T., Moreno-Marí, J., Pujade-Villar, J. and Jiménez-Peydró, R. (2006) Fenología de los Bracónidos (Hymenoptera, Braconidae) del Pirineo Andorrano. Pirineos, 161, 111-132. http://dx.doi.org/10.3989/pirineos.2006.v161.5

[17] Peris-Felipo, F.J. and Jiménez-Peydró, R. (2011) Biodiversity within the Subfamily Alysiinae (Hymenoptera, Braconidae) in the Natural Park Peñas de Aya (Spain). Revista Brasileira de Entomologia, 55, 406-410. http://dx.doi.org/10.1590/S0085-56262011005000042

[18] Jiménez-Peydró, R. and Peris-Felipo, F.J. (2011) Diversity and Community Structure of Opiinae (Hymenoptera: Braconidae) in the Forest Estate of Artikutza (Spain). Florida Entomologist, 94, 472-479. http://dx.doi.org/10.1653/024.094.0311

[19] Pérez-Rodríguez, J., Oltra-Moscardó, M.T., Peris-Felipo, F.J. and Jiménez-Peydró, R. (2013) Microgastrinae (Hymenoptera: Braconidae) in the Forest State of Artikutza (Navarra: Spain): Diversity and Community Structure. Insects, 4, 493-505. http://dx.doi.org/10.3390/insects4030493

[20] Peris-Felipo, F.J. and Jiménez-Peydró, R. (2012) Cerambycidae (Coleoptera) Diversity and Community Structure in the Merditerranean Forest of the Natural Park of Sierra Calderona (Spain). Frustula Entomologica, 33, 180-191.

[21] Achterberg, van C. (1990) Illustrated Key to the Subfamilies of Holartic Braconidae (Hymenoptera: Ichneumonoidea). Zoologische Mededelingen Leiden, 64, 1-20.

[22] Hammer, O., Harper, D. and Ryan, P. (2001) PAST: Paleontological Statistics Software for Education and Data Analysis. Paleontología Electrónica, 4, 1-9.

[23] Magurran, A.E. (1991) Ecological Diversity and Its Measurenment. Chapman and Hall, London.

[24] Soares, S.A., Antonialli-Junior, W.F. and Lima-Junior, S.E. (2010) Diversidade de Formigas Epigéicas (Hymenoptera, Formicidae) em Dois Ambientes no Centro-Oeste do Brasil. Revista Brasileira de Entomologia, 54, 76-81. http://dx.doi.org/10.1590/S0085-56262010000100009

[25] Tokeshi, M. (1993) Species Abundance Patterns and Community Structure. Advances in Ecological Research, 24, 111186. http://dx.doi.org/10.1016/S0065-2504(08)60042-2

[26] Krebs, C.J. (1999) Ecological Methodology. Benjamin Cummings, Menlo Park.

[27] Zar, J.H. (1999) Biostatistical Analysis. Prentice Hall, Upper Saddle River.

[28] Rougerie, R., Smith, A.R., Fernandez-Triana, J., Lopez-Vaamonde, C., Ratnasingham, S. and Hebert, P.D.N. (2010) Molecular Analysis of Parasitoid Lonkages (MAPL): Gut Contents of Adult Parasitoid Wasps Reveal Larval Host. Molecular Ecology, 20, 179-186. http://dx.doi.org/10.1111/j.1365-294X.2010.04918.x 